\title{
New species of genus Tarsozeuzera Schoorl, 1990 (Lepidoptera: Cossidae: Zeuzerinae) from Sulawesi Island
}

\author{
Новый вид рода Tarsozeuzera Schoorl, 1990 \\ (Lepidoptera: Cossidae: Zeuzerinae) с острова Сумавеси
}

\author{
R.V. Yakovlev \\ Р.В. Яковлев
}

\footnotetext{
${ }^{1}$ Altai State University, pr. Lenina 61, Barnaul 656049, Russia. E-mail: yakovlev_asu@mail.ru

2 Tomsk State University, Laboratory of Biodiversity and Ecology, Lenina pr. 36, 634050 Tomsk, Russia.

${ }^{1}$ Алтайский государственный университет, пр. Ленина 61, Барнаул 656049, Россия.

2 Томский государственный университет, Лаборатория биоразнообразия и экологии, пр. Ленина 36, Томск 634050, Россия.
}

KEY WORDS: Lepidoptera, Carpenter moths, Zeuzerinae, fauna, Indonesia, Tarsozeuzera.

КЛЮЧЕВЫЕ СЛОВА: Lepidoptera, древоточцы, Zeuzerinae, фауна, Индонезия, Tarsozeuzera.

ABSTRACT. The article describes a new species, Tarsozeuzera prashkevitchi Yakovlev sp. n. from the island of Sulawesi (Indonesia) — the fifth species of the genus reported from South-East Asia. The description is provided with a detailed diagnosis and illustrations.

РЕЗЮМЕ. В статье описан новый вид Tarsozeuzera prashkevitchi Yakovlev sp. n. с острова Сулавеси (Индонезия) - пятый вид рода, отмеченный в Юго-Восточной Азии. Описание снабжено подробным диагнозом и проиллюстрировано.

\section{Introduction}

The genus Tarsozeuzera Schoorl, 1990 includes six described species, widely spread in the tropics of the Old World. Tarsozeuzera fuscipars (Hampson, 1892) was reported from N. India, Myanmar, Laos, Borneo, Vietnam, Thailand, China (Yunnan, Hubei) [Arora, 1976; Yakovlev, 2014; Yakovlev et al., 2018]; T. kochi (Semper, 1896) is an endemic of Philippines (indicated for the islands Panay, Luzon, Negros, Palawan, Mindanao, Leyte, and Mindoro) [Yakovlev et al., 2018]; T. livingstoni Yakovlev, 2006 is found in Gabon, Congo, Cameroon, Cote d'Ivoire, Malawi, Kenya, Sierra Leone, Tanzania, Zimbabwe, Zambia [Yakovlev, 2011; Yakovlev, Murphy, 2013; Yakovlev et al., 2019a, b]; $T$. miklukhomaklayi Yakovlev, 2011 — in New Guinea; T. ustjuzhanini Yakovlev, 2011 — in South Africa (Kwa Zulu-Natal Prov.), and T. vavizola Yakovlev, 2006 in S. Thailand.

During the examination of specimens in the entomological collection of the Natural History Museum, Lon- don (later, NHMUK) the author found a small series of a species from Sulawesi, new to science. The description is given below.

\section{Material and methods}

Slides were photographed using an Olympus DP74 camera attached to an Olympus SZX16 stereomicroscope at Altai State University. The type material is deposited in NHMUK.

\section{Taxonomical part}

Tarsozeuzera prashkevitchi Yakovlev, sp.n. Figs 1-3.

MATERIAL: holotype, $\sigma^{7}$, Indonesia, Sulawesi Utara, Dumoga Bone NP, January 1985, Toraut base Camp, 200 m, 9.i.1985, J.D. Holloway, specimen photo number: 012832515 , slide number: 010315543. Paratypes: $10^{7}, 1$ 우, [Indonesia], G. Paloe, Tampoe, West Celebes [Sulawesi], 2.700', Jan. 1937, (J.P.A. Kalis), specimen photo numbers: $012832479\left(\mathrm{O}^{7}\right), 012832517\left({ }^{\circ}\right)$, slide number: $010315510\left(O^{7}\right)$.

DESCRIPTION. Length of male fore wing 18-20 mm. Antenna bipectinate from base to half of length, distally not pectinate. Thorax on upper side covered with brown scales interspersed with white scales, laterally thin lines of light scales. Fore wing elongated, apically sharp, light-creamy, wide greyish-bluish portion medially, reticulated brown pattern along all wing edges. Hind wing significantly shorter than fore wing, light-creamy, sprayed with greyish scales, reticulated brown pattern along outer edge and in anal angle area.

Male genitalia. Uncus relatively short, gradually narrowing from base to apex, mastoid semicircular process apically; tegumen of medium size; valve wide, simple, edges even,

How to cite this article: Yakovlev R.V. 2020. New species of genus Tarsozeuzera Schoorl, 1990 (Lepidoptera: Cossidae: Zeuzerinae) from Sulawesi Island // Russian Entomol. J. Vol.29. No.2. P.207-209. doi: 10.15298/ rusentj.29.2.15 
relatively short; gnathos arms very thin, ribbon-like; gnathos reduced; juxta trapezoidal with small leaf-like lateral processes; saccus semicircular, small. Phallus robust, short (slightly shorter than valve), slightly curved in basal third, longitudinal folds in distal third, large finger-like cornutus in dorsal part of vesica.

Female. Length of fore wing $33 \mathrm{~mm}$. Antenna simple, not pectinate. Fore wing long, apically rounded. Wing pattern identical to that of male.

DIAGNOSIS. Among all species of the genus, externally may be confused with $T$. fuscipars and $T$. kochi. Differs from the closest species in the following characters:

- T. fuscipars and T. kochi are slightly smaller (length of the male fore wing is $15-19 \mathrm{~mm}$ );

- T. fuscipars and T. kochi have more expressed brown pattern on the fore wing (especially along the rear edge of the wing);

- the valve in T. fuscipars and T. kochi is significantly narrower basally (in $T$. prashkevitchi sp. nov. the valve is wide, with even edges)

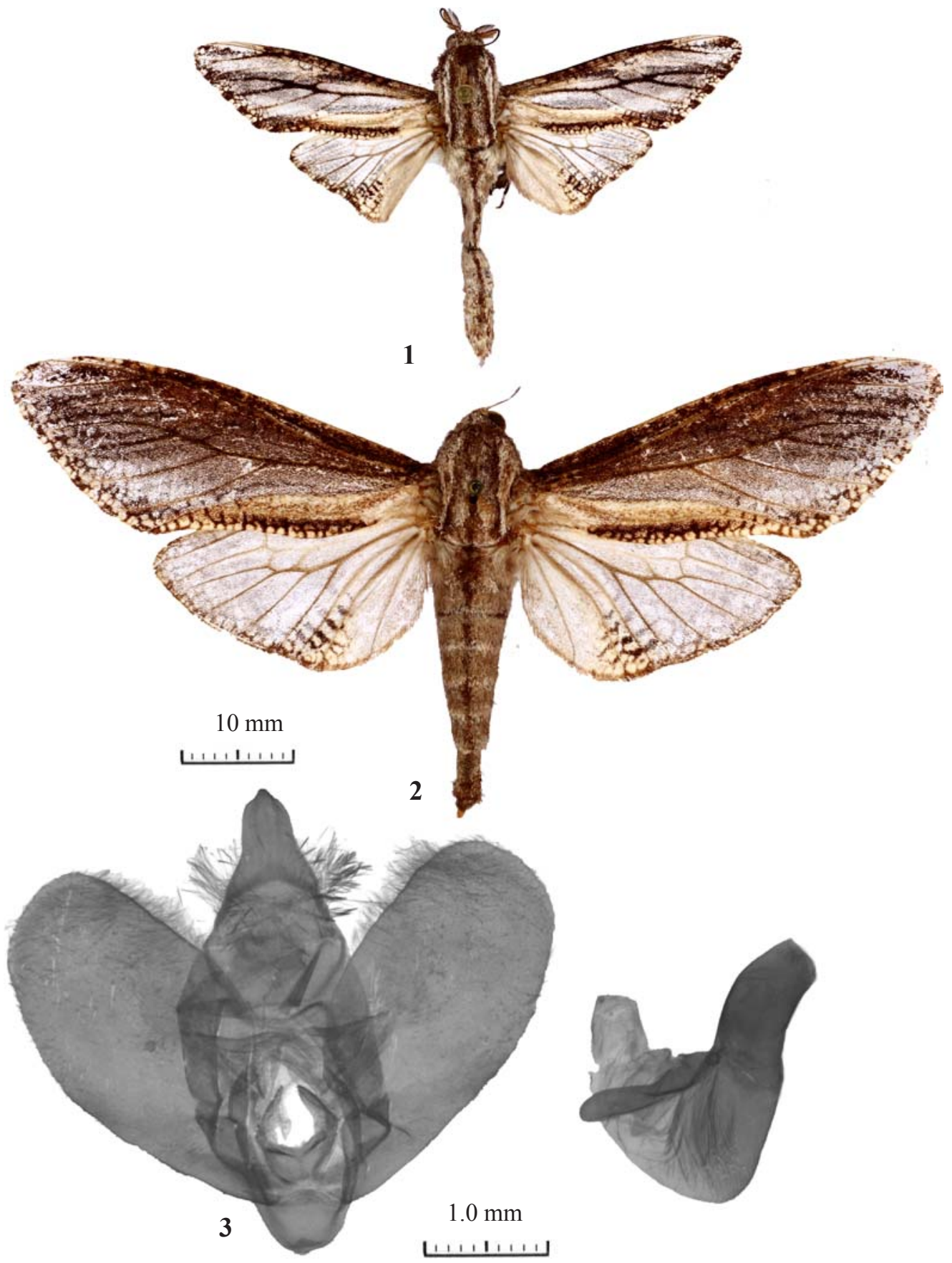

Figs 1-3. Tarsozeuzera prashkevitchi Yakovlev, sp.n.,: 1 - habitus, holotype, ơ'; 2 - habitus, paratype, + ; 3 - genitalia of holotype (slide 010315543).

Рис. 1-3. Tarsozeuzera prashkevitchi Yakovlev, sp.n.: 1 — голотип, О’; 2 - паратип, + ; 3 - гениталии голотипа (slide 010315543). 
ETYMOLOGY. The new species is named after the wellknown talented Russian writer, Gennady Prashkevich (Novosibirsk).

Acknowledgements. The author are indebted to Mr. Geoff Martin and Mr. Alessandro Giusti (NHMUK, London) for their kind assistance provided during studying the type material of the Natural History Museum. The author are also grateful to Anna Ustjuzhanina (Tomsk, Russia) for linguistic corrections of the manuscript and to Miss Kseniya Proskuryakova (Moscow, Russia) for preparing genitalia slides.

\section{References}

Arora G.S. 1976. A taxonomic revision of the Indian species of the family Cossidae (Lepidoptera) // Records of the Zoological Survey of India. Vol.69. Nos 1-4. P.1-160.
Yakovlev R.V. 2011. Catalogue of the Family Cossidae of the Old World (Lepidoptera) // Neue Entomologische Nachrichten. Bd.66. P.1-130.

Yakovlev R.V. 2014. Descriptions of three new species of Cossidae (Lepidoptera) from Vietnam, with an updated annotated checklist // Zootaxa. Vol.3802. No.2. P.240-256.

Yakovlev R.V., Murphy R.J. 2013. The Cossidae (Lepidoptera) of Malawi with descriptions of two new species //Zootaxa. Vol.3709. No.4. P.371-393. DOI: 10.11646/zootaxa.3709.4.5.

Yakovlev R.V., Laszlo G.M., Witt T.J. 2019a. First records of Cossidae from Gabon (West Africa) (Lepidoptera: Cossidae) // SHILAP Revista de lepidopterologia. Vol.47. No.186. P.279283.

Yakovlev R.V., Laszlo Gy.M., Witt T.J. 2019b. First summary of Cossidae of Sierra Leone (West Africa) (Lepidoptera: Cossidae) // SHILAP Revista de lepidopterologia. Vol.47. No.187. P.557565.

Yakovlev R.V., Sokolova G.G., Witt Th. 2018. Cecryphalini Yakovlev et Witt, trib. n. - new tribe of CarpenterMoths (Lepidoptera: Cossidae: Zeuzerinae)// Russian Entomological Journal. Vol.27. No.4. P.415-424. doi: 10.15298/rusentj.27.4.09. 